\title{
Gonadal defects in Cited2 -mutant mice indicate a role for SF1 in both testis and ovary differentiation
}

\author{
ALEXANDER N. COMBES ${ }^{1}$, CASSY M. SPILLER ${ }^{1}$, VINCENT R. HARLEY ${ }^{2}$, ANDREW H. SINCLAIR ${ }^{3}$, \\ SALLY L. DUNWOODIE ${ }^{4,5}$, DAGMAR WILHELM ${ }^{1}$ and PETER KOOPMAN* ${ }^{*} 1$

\begin{abstract}
${ }^{1}$ Division of Molecular Genetics and Development, Institute for Molecular Bioscience, The University of Queensland, Brisbane, QLD, ${ }^{2}$ Prince Henry's Institute of Medical Research, Melbourne, VIC, ${ }^{3}$ Murdoch Children's Research Institute, and Dept. of Paediatrics, University of Melbourne, Royal Children's Hospital, Melbourne, VIC, ${ }^{4}$ Developmental Biology Division, Victor Chang Cardiac Research Institute, Darlinghurst, Sydney, NSW and ${ }^{5}$ Faculty of Medicine, University of New South Wales, Kensington, Sydney, NSW, Australia
\end{abstract}

\begin{abstract}
Sex determination is regulated by a molecular antagonism between testis- and ovarydetermining pathways in the supporting cell lineage of the gonadal primordia. Genes important for maintaining this lineage play critical roles in early gonadal development, but their influence on testis and ovary differentiation is unclear due to the severity of loss-of-function phenotypes. The transcription factor SF1 (Nr5a1/Ad4BP) is one such factor, required for establishing the supporting cell lineage, and for propagating the male pathway. In the gonad, Sf1 expression is enhanced by the transcriptional co-factor Cited2. We have used the reduced levels of Sf1 expression in Cited2 ${ }^{-/}$mice as a hypomorphic model to gain insight into the sex-specific roles of SF1 function in gonadal development. In XY mutant mice, we found that testis development was delayed in Cited2 $\%$ gonads, and that testis structure was permanently disrupted. In XX Cited2\% gonads, ectopic cell migration was observed which correlated with a transient upregulation of Fgf9, and a delay in Wnt4 then Foxl2 expression. These data suggest a novel role for SF1 in promoting ovarian development in addition to its roles in testis differentiation.
\end{abstract}

KEY WORDS: cited2, SF1, testis development, ovary development, antagonism

\section{Introduction}

Sex determination is regulated by competing molecular pathways in the supporting cell lineage of the bipotential gonad (Capel, 2000). Some transcription factors expressed in this lineage play critical roles in the development of the genital ridge, yet their expression is maintained after sex determination. The extent to which these factors influence testis or ovary differentiation after the early gonad has formed remains unclear.

The genital ridges develop from the intermediate mesoderm on either side of the neural tube from 9 days post coitum (dpc) (Capel, 2000). Subsequently, genes promoting testis or ovarian development are expressed in the genital ridge to determine gonadal sex. The expression of wingless-related MMTV integration site 4 (Wnt4), R-spondin1 (Rspo1), and $\beta$-Catenin at this stage promotes ovary development while opposing testis development (Chassot et al., 2008, Kim et al., 2006, Liu et al., 2009, Maatouk et al., 2008, Tomizuka et al., 2008, Vainio et al., 1999). Conversely, expression of fibroblast growth factor 9 (Fgfg)promotes testis development while repressing ovarian fate (Kim et al., 2006). The expression of Sex determining region of the $Y$ chromosome (Sry) in XY gonads tips the balance of these opposing signals towards testis development by upregulating Sry-related homeobox-containing gene 9 (Sox9), with assistance from steroidogenic factor 1 /nuclear receptor subfamily 5 , group $A$, member 1/ adrenal 4-binding protein (SF1/Nr5a1/Ad4BP) (Sekido and Lovell-Badge, 2008). Sox9 expression results in upregulation of paracrine signals FGF9 (Kim et al., 2006) and prostaglandin D2 (Wilhelm et al., 2007), which in turn, promote Sox9expression in undifferentiated somatic cells (Kim et al., 2006; Moniot et al., 2009; Wilhelm et al., 2005), leading to repression of Wnt4. In an XX environment, in the absence of SRY, the WNT signal prevails to repress Fgfg expression and promote ovarian development (Kim et al., 2006). Disruption or delay in expression of genes in either pathway can lead to partial or full development of the

Abbreviations used in this paper: dpc, days post coitum.

\footnotetext{
*Address correspondence to: Peter Koopman. Division of Molecular Genetics and Development, Institute for Molecular Bioscience, The University of Queensland, Brisbane, QLD 4072, Australia. Fax: +61-7-3346-2101. e-mail: p.koopman@imb.uq.edu.au - web: http://www.imb.uq.edu.au/groups/koopman
} 
opposing fate, resulting in sex reversal.

SF1 plays a number of important roles in gonadal development. In mice lacking $S f 1$, the genital ridges form initially, then progressively degenerate through apoptosis, and are entirely absent by $12.5 \mathrm{dpc}$ (Luo et al., 1994). SF1 is expressed in the genital ridge from $9.5 \mathrm{dpc}$, under the regulation of Wilms tumor suppressor protein 1 (WT1) (Wilhelm and Englert, 2002). Subsequently, SF1 acts as a cofactor to upregulate the male sex determining gene Sox9 (Sekido and Lovell-Badge, 2008) and its target anti-Müllerian hormone (Arango et al., 1999) to propagate the male pathway. SF1 is also expressed in steroidogenic cells in both sexes at later stages (Ikeda et al., 2001). Currently it is unclear whether SF1 influences the transcriptional program of early ovarian development outside its role in steroidogenesis.

Regression of the gonads after sex determination in Sf1 knockout mice prevents a full analysis of the roles of this gene in gonadal differentiation (Luo et al., 1994, Sadovsky et al., 1995). However, a conditional allele for this gene exists and has been used to study the cell-specific roles of $\mathcal{S} f 1$ (Jeyasuria et al., 2004). Additionally, $\mathcal{S} f 1$ function is dose-sensitive, so $S f 1$-haploinsufficient mice have been used to gain insight into downstream target genes (Park et al., 2005).

We reasoned that a hypomorphic mouse model might provide further insight into the functions of SF1 in gonadal differentiation. Mice lacking CBP/p300-interacting transactivator with Glu/Asprich carboxy-terminal domain 2 (Cited2) provide a suitable model as Cited2 interacts with WT1 and enhances, but is not required for, gonadal expression of $S f 1$ (Val et al., 2007). Cited2 is expressed briefly in the gonadal primordia at $10 \mathrm{dpc}$. However, after $10.5 \mathrm{dpc}$, expression in the gonad is minimal until it is expressed again at low levels at $13.5 \mathrm{dpc}$ (Val et al., 2007). Sf1 expression is reduced in Cited $2^{\%}$ mice, resulting in a transcriptional delay of the male program of development. Sry, Sox9, and other male markers are expressed later and at lower levels than in wild type controls (Val et al., 2007). However, these levels are corrected by $13.5 \mathrm{dpc}$, and gonads have been reported to develop normally from this point (Bamforth et al., 2001, Val et al., 2007). The brief window of Cited2 expression early in gonadal development suggests that the delay in testis development in these mice (Val et al., 2007) is caused by the loss of Cited2 -mediated enhancement of $S f 1$ levels, rather than a direct effect by loss of Cited2.

We used the low levels of $S f 1$ in Cited2 $2^{--}$mice as a hypomorphic model to study the roles of SF1 in testis and ovary development. In agreement with published studies, testis development was delayed. However, we found that despite recovery at the

Fig. 1. Abnormal testis morphology in Cited2/-mice. (A-C) Representative images of gonadal morphology from 12.5 - $14.5 \mathrm{dpc}$ Cited $2^{+/+}$and Cited $2^{+/-}$embryos. Asterisks indicate testis cords and an arrow indicates the coelomic vessel. (D-F) Abnormal morphology in Cited2\% gonads demonstrates that testis development is defective in embryos lacking this gene. Arrows indicate the coelomic vessel, brackets highlight regions where Sertoli and germ cells are not organised into testis cords, asterisks mark testis cords. A-F, Sertoli cells are marked by an anti-SOX9 antibody (green). A, B, D, E are confocal images of wholemount gonads; germ cells and vasculature are marked by an anti PECAM-1 antibody (red). $C$ and $F$ are confocal images of paraffin sections; germ cells are marked by an anti-OCT4 antibody (red). $n \geq 3$ for each knockout stage analysed. Scale bar, $100 \mu \mathrm{m}$ transcriptional level, testis cord organisation and morphology were more permanently disrupted. Further we uncovered a novel role for SF1 in promoting ovary development through enhancing expression of Wnt4 and Fox/2. We found that the male pathway was not fully repressed in the early ovary. Consequently, Fgfg was transiently upregulated, and ectopic cell migration was induced before a resurgence of the female transcriptional program. These results reveal a novel role for SF1 in promoting ovarian development.

\section{Results}

\section{Disrupted gonadal morphology in Cited2 ${ }^{-/} X Y$ gonads}

We first investigated gonadal morphology in the Cited2 null mouse to determine whether the reported delay and recovery of gene expression driving testis development (Val et al., 2007) also occurred at the cellular and morphological levels. Wild type (Cited2 ${ }^{+/+}$) and heterozygous knockout (Cited2 ${ }^{+/}$) gonads were morphologically similar and were used interchangeably as controls when comparing testis structure.

At $12.5 \mathrm{dpc}$, Cited2 ${ }^{+/+}$testes had an established coelomic blood vessel (Fig. 1A, arrow) and distinct vasculature between clearly segmented testis cords (Fig. 1A, asterisks). In comparison, homozygous knockout (Cited2 $\%$ ) XY gonads of the same age lacked testis cord organisation (Fig. 1D, brackets), and had a severely reduced, and discontinuous, coelomic blood vessel (Fig. 1D, arrow). By $13.5 \mathrm{dpc}$, when testis cords had become more regular in wild type gonads (Fig. 1B), knockout gonads of the same age were still severely disrupted (Fig. 1E). Large regions of the gonad remained disorganised (Fig. 1E, bracket), while in other

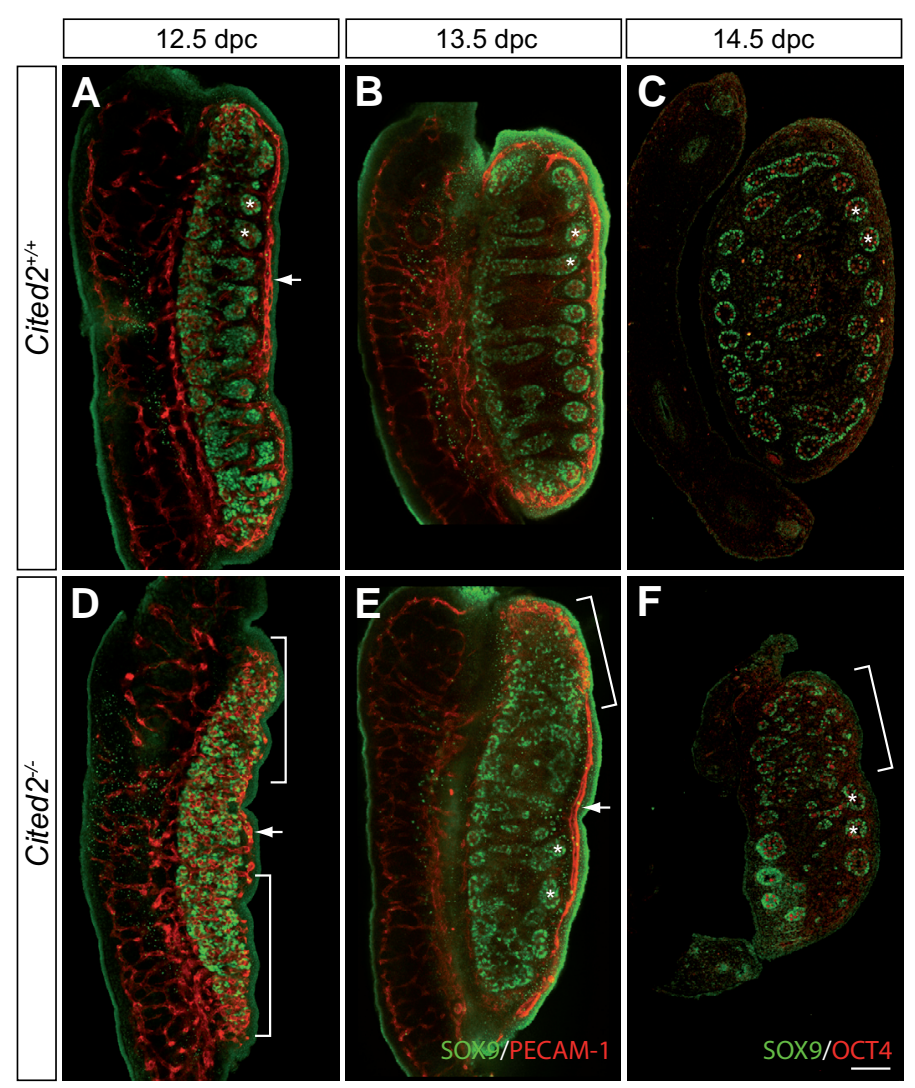


areas, testis cords and the coelomic vessel had formed (Fig. 1E, asterisks and arrow). $13.5 \mathrm{dpc}$ knockout testis morphology did not resemble $12.5 \mathrm{dpc}$ wild type testis morphology, as would be expected if testis organisation was simply delayed. At $14.5 \mathrm{dpc}$, wild type gonads had increased in size and retained regular cord organisation (Fig. 1C), whereas knockout gonads were smaller and had a mixture of disorganised regions and areas where cord formation had occurred (Fig. 1F; $n \geq 3$ for each knockout stage analysed).

In summary, testis morphology was disrupted in $X Y$ gonads lacking Cited2, with no stage of cord development resembling wild type. Thus, although a delayed transcriptional program recovers to normal levels by $13.5 \mathrm{dpc}$ (Val et al., 2007), knockout testis morphology did not recover by $14.5 \mathrm{dpc}$, implicating Cited2 and threshold levels of $S f 1$ as a requirement for establishing normal testis morphology.

\section{Ectopic cell migration in Cited $2^{-/} X X$ gonads}

Because testis cord formation is critically dependent on endothelial cell migration from the mesonephros (Cool et al., 2008; Combes et al., 2009), we reasoned that a lack of cord organisation might indicate compromised cell migration into the testis. To test this hypothesis, we assessed the competency of $11.5 \mathrm{dpc} \mathrm{Cited}^{+/-}$and Cited ${ }^{-/}$gonads and mesonephroi to induce and respond to cell migration cues respectively. We found that cells within Cited2-/mesonephroi were able to respond to migration cues from wild type testes (Fig. 2 A-C), and although Cited ${ }^{\%}$ testes were considerably smaller than their wild type or heterozygous counterparts, they were still able to induce cell migration from wild type mesonephroi (Fig. 2 D-F). Surprisingly, loss of one or two functional Cited2 alleles from an XX gonad resulted in ectopic cell migration (Fig. 2 G-I). To compare levels of cell migration in $X X$ gonads of different genotypes we determined the number of GFPpositive units, as a proxy for the number of migrating cells, in the gonadal compartment of each $\mathrm{XX}$ gonad and plotted the individual, and averaged results (Fig. $2 \mathrm{~J}, \mathrm{~K}$ ). Background levels of migration were observed in wild type $X X$ gonads with an average of $6 \pm 0.8$ GFP-positive units detected per gonad $(n=5)$. However, $24 \pm 3.9(n=4)$ units were detected in Cited $2^{+/-} X X$ gonads, and this number doubled to $51 \pm 8(n=5)$ in-Cited $\%$ XX gonads. Thus, loss of functional Cited2alleles, and the corresponding decrease in SF1, does not have an overt influence on cell migration in the $X Y$ gonad, but causes a dose-dependent de-repression of cell migration in the $\mathrm{XX}$ gonad.

\section{Transient upregulation of the male pathway in Cited2 ${ }^{-/-} X X$ gonads}

Under normal conditions, mesonephric cell migration is repressed by WNT signalling in XX gonads as part of the program of ovarian development (Chassot et al., 2008, Jeays-Ward et al., 2003, Liu et al., 2009, Tomizuka et al., 2008). To determine whether the ectopic cell migration we observed correlated to a disruption or delay in the ovarian program, we assessed expression levels of $S f 1$, key initiators of the WNT signalling pathway (Wnt4, Rspo1), and the female marker gene forkhead box L2 (Fox/2) from 10.5 to $13.5 \mathrm{dpc}$ in XX Cited2\% gonads (Fig. 3). In parallel, we assessed the male markers Sox9and Fgf9to test for ectopic activation of the male pathway.

As expected, Sf1 expression was reduced in Cited2 ${ }^{-} \mathrm{XX}$ gonads at 10.5 and $11.5 \mathrm{dpc}$ (Fig. 3A, B) in comparison to Cited2 +/- and Cited $2^{+/+}$littermates. However by $12.5 \mathrm{dpc}, S f 1$ levels were similar between homozygous-null and wild type gonads (Fig. 3C),
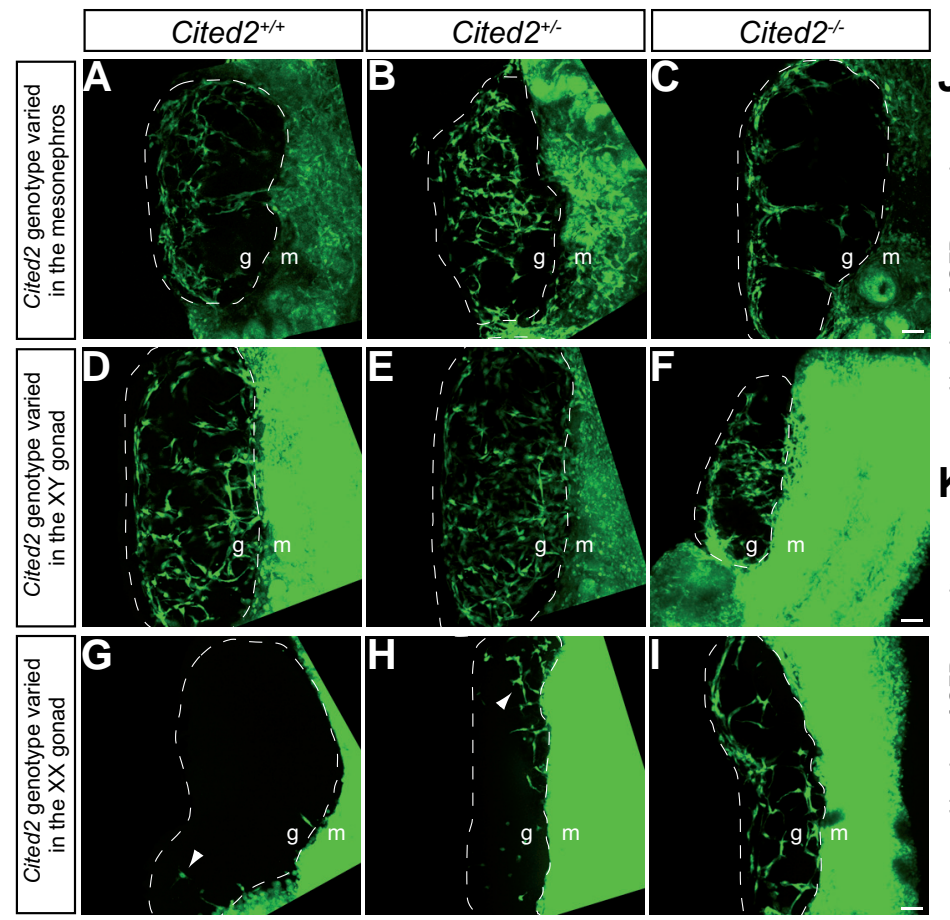

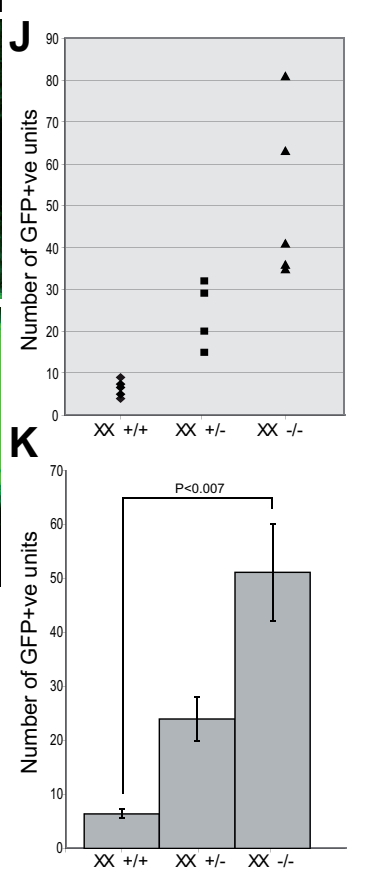

Fig. 2. Cited2 represses ectopic migration in XX gonads but does not grossly influence migration in $\mathrm{XY}$ gonads. The influence of Cited2 on mesonephric cell migration was determined by assaying Cited2 ${ }^{+/+}(+/+)$, Cited2 ${ }^{+/}(+/-)$, and Cited2 - (-/-): mesonephroi (A-C), XY gonads (D-F), and $X X$ gonads (G-I). Boxed text to the left of each row indicates the tissue in which the genotype was varied. The genotype of the varied tissue is indicated above each column. (A-C) Loss of Cited2 from the mesonephros did not impair cell migration into an $X Y$ gonad $\mathrm{n}>3$ for all. (D-F) Loss of Cited2 from the $X Y$ gonad did not impair cell migration, although the size of the Cited $2 \%$ gonad was reduced $\mathrm{n}>3$ for all. (G-I) Loss of Cited2 from the XX gonad resulted in ectopic cell migration into Cited2 $2^{+-}$gonads which was increased in Cited2-- gonads. An arrowhead in $\mathrm{G}$ indicates background levels of migration that occur under normal $\left(\right.$ Cited $2^{+/+}$) conditions. g, gonad; $m$, mesonephros. Scale bars, 50 $\mu \mathrm{m}$. (J) Quantitation of ectopic cell migration in multiple $X X$ Cited $2^{+-}$and Cited $2 \%$

gonads, compared to Cited2 ${ }^{+/+} X X$ controls. Results for individual experiments are plotted as separate data points $(+/+n=5,+/-n=4,-/-n=5)$. (K) Mean number of migrating cells from the data set used in J. Error bars represent the standard error of the mean. $p<0.007$ for the difference between Cited $2^{+1}$ + and Cited $2 \%$. Some images displayed in Figure 2 have been rotated and displayed on a black background for presentation purposes. 
indicating that Cited2 enhances initial expression of $S f 1$, but that continued Sf1 expression is independent of Cited2.

Pro-ovary genes- Wnt4, Rspo1, and Fox/2-followed a similar trend to $S f 1$, being expressed at reduced levels at $10.5 \mathrm{dpc}$ (Fig. $3 \mathrm{D}, \mathrm{G}, \mathrm{J})$. The reduction in Wnt4 between wild type and null gonads was statistically significant $(p<0.031)$, whereas the reduction in Rspo 1and Fox/2 was not. The reduced expression of these genes persisted at $11.5 \mathrm{dpc}$ with a significant reduction in levels of Fox/2 (Fig. $3 \mathrm{E}, \mathrm{H}, \mathrm{K}$ ). By $12.5 \mathrm{dpc}$, levels of Wnt4, Rspo1, and Fox/2 in Cited2null gonads were comparable to wild type levels, indicating a recovery of the female transcriptional program (Fig. $3 \mathrm{~F}, \mathrm{I}, \mathrm{L})$. These data implicate $S f 1$ in promoting the program of ovarian differentiation.

The decreased expression of Wnt4, Rspo1, and Fox/2 corre-
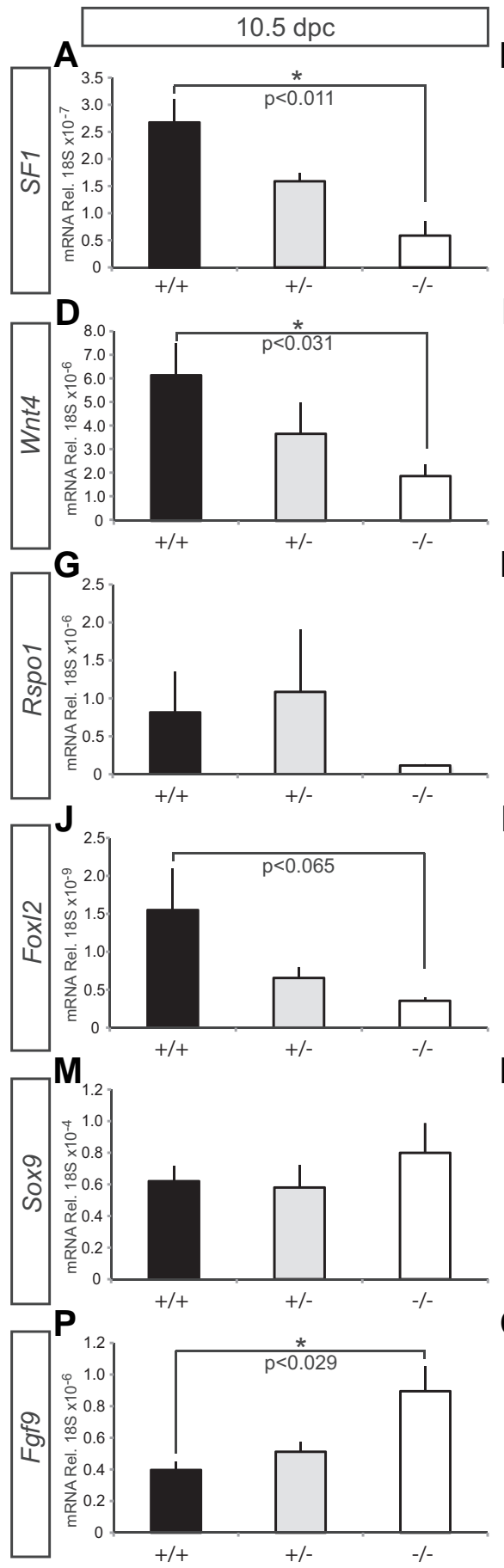

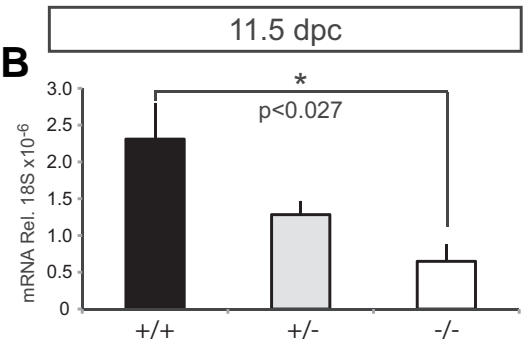

E

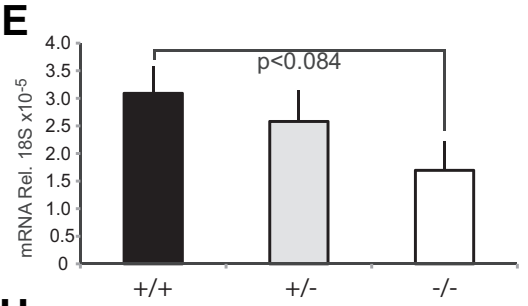

H

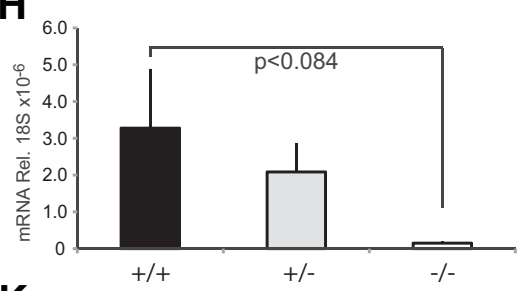

K

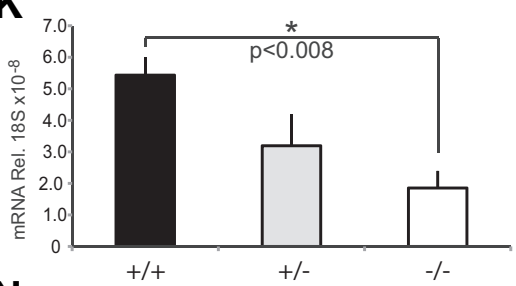

N

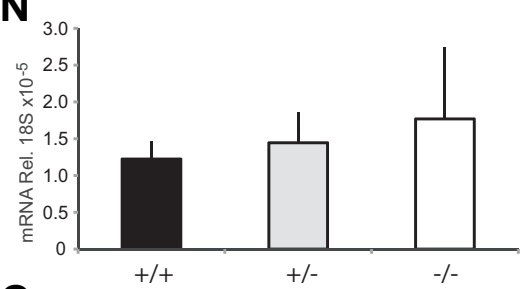

Q

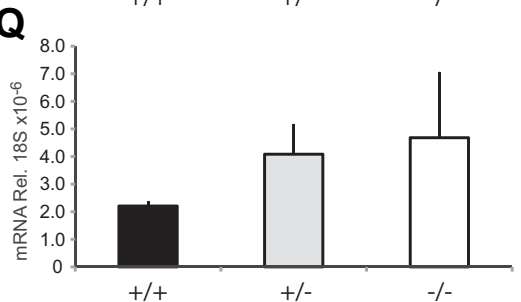

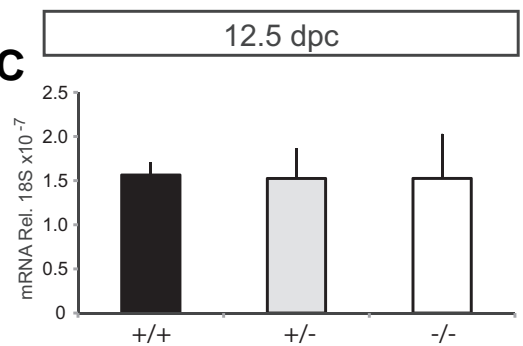

F

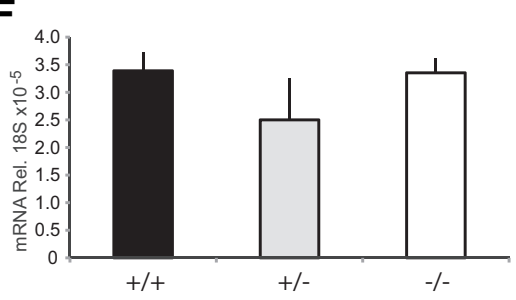

I

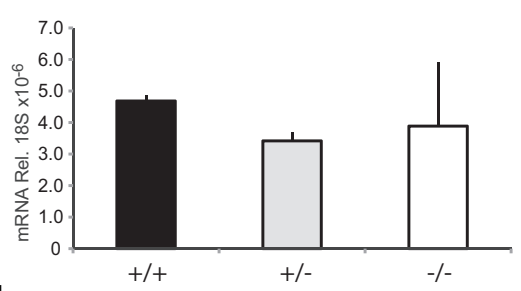

L
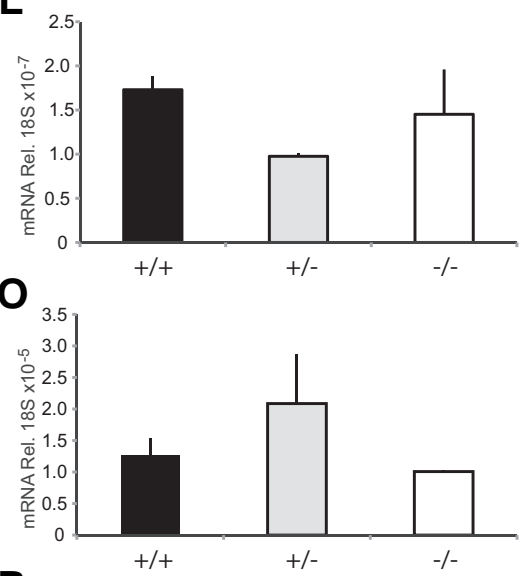

R

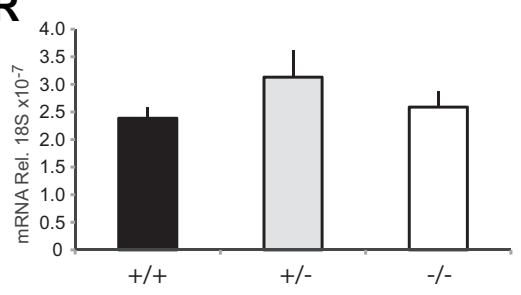

Fig. 3. Expression profiling of $\mathbf{S f 1}$, and key female and male markers in Cited2 XX gonads. Quantitative real time $R T-P C R$ for: (A-C) Sf1, (D-F) Wnt4, (G-I) Rspo1, (J-L) Foxl2, (M-O) Sox9, and (P-R) Fgf9, in Cited2 ${ }^{+/+}(+/+)$, Cited2+- (+/-), and Cited2 ${ }^{--}(-)$XX gonads from 10.5 - 12.5 dpc. $\mathrm{n}=$ 3 for all samples and bars indicate the standard error of the mean. 
lated with increased levels of Sox9, and a statistically significant increase of $F$ ffg in the same homozygous gonads (Fig. 3 $M, N, P, Q)$. However the higher levels of expression were transient and reduced to those of wild type controls by $12.5 \mathrm{dpc}$ (Fig. $3 \mathrm{O}, \mathrm{R}$ ).

Overall, these data indicate that in the absence of Cited2, decreased $S f 1$ levels cause a delay in the female program of development. This delay results in a transient upregulation of male markers and ectopic induction of cell migration, but is shortlived because the initial delay in the program of ovarian differentiation is corrected, or compensated for, by $12.5 \mathrm{dpc}$.

\section{Discussion}

In this study we used mice lacking Cited2, an established enhancer of $S f 1$ expression, as a hypomorphic model to study the effect of reduced levels of $S f 1$ on testis and ovarian development. We found that testis morphology was not only delayed, but severely disrupted, and did not recover by $14.5 \mathrm{dpc}$. Furthermore, we assayed cell migration and found that migration was not disrupted in XY gonads or mesonephroi lacking Cited2. However, ectopic cell migration was observed in the $X X$ gonad in a dosedependent response to loss of functional Cited2 alleles. Correspondingly, the female pathway was initially delayed but recovered shortly after, implicating $S f 1$ in the initiation of ovarian development. These data underscore the fragility of the molecular control of sex determination, in that reduced levels of $S f 1$ in the male disrupt testis morphology, whereas in the female, promoters of the male pathway are not sufficiently suppressed. However, the recovery of both pathways at the transcriptional level demonstrates compensatory mechanisms that act to reinforce sexual differentiation in the face of disruptions.

A central assumption of our study is that Cited2\% mice are a suitable model in which to study gonadal development. Embryos lacking Cited2 die between 13.5 and 17.5 dpc (Weninger et al., 2005) with multiple developmental defects including cardiac malformations and exencephaly (Bamforth etal., 2001, Barbera etal., 2002, Yin et al., 2002). Placental insufficiency, which impacts on embryo growth between 12.5 and $14.5 \mathrm{dpc}$, is the likely cause of death (Withington et al., 2006). However, these defects do not appear to have a major influence on the early stages of gonadal development as testis morphology has previously been reported to be normal prior to death in embryos homozygous for a different Cited2 knockout allele to the one used in this study (Bamforth et al., 2001; Val et al., 2007).

Instead, we view the delay in gonadal development observed in Cited $2^{-/}$mice as a result of reduced levels of SF1. SF 1 is known to promote the testis pathway through transcriptional regulation of key testis-determining genes (Arango et al., 1999, Sekido and Lovell-Badge, 2008, Wilhelm and Englert, 2002). Genetic and biochemical evidence supports a role for Cited2 together with $W t 1$ in enhancing gonadal expression of Sf1 (Buaas et al., 2009, Val et al., 2007). Further, we and others show that the delay and recovery of male (Val et al., 2007), and female (this study) transcriptional programs correlate with a delay and recovery of $S f 1$ levels. However, we cannot exclude the potential influence of low oxygen and nutrient levels caused by placental insufficiency in these mice (Withington et al., 2006), nor the potential for Cited2 to influence other genes important for testis or ovarian development.
We found that the disruptions in testis morphology were not due to a reduction in cell migration. What, then, is responsible for the defects in cord organisation seen in Cited $2^{-/}$gonads? It is well established that threshold levels and correct timing of Sryand Sox9 expression are required for initiation of the male pathway (Bullejos and Koopman, 2005, Hacker et al., 1995). However, SOX9 protein was detected along the length of the Cited $\%$ gonad by $12.5 \mathrm{dpc}$ (Fig. 1B), indicating significant activation of the male program throughout the testis at this stage. Furthermore, lower levels of $S f 1$ and a delay in target gene expression in $S f 1$-haploinsufficient mice do not affect gross cord structure or function (Park et al., 2005). It is possible that differences in SF1 levels, or background strains, between our Cited $\%$ model and the $S f 1$-haploinsufficient mice could result in a more severe delay in testis development and disrupted cord formation. Alternatively, the cord defects may be caused or amplified by deprivations resulting from placental insufficiency in these mice (Withington et al., 2006), or by loss of an unknown Cited2-regulated factor required for cord organisation.

The disruption to development in Cited2\% ovaries suggests an additional and previously unsuspected role for SF1 in initiating ovary development through direct or indirect mechanisms. The induction of ectopic cell migration in the ovary indicates that one role of SF1 is to promote WNT signalling, which usually represses this event (Chassot et al., 2008, Jeays-Ward et al., 2003, Liu et al., 2009, Tomizuka et al., 2008). This link is supported by the reduced levels of $W n t 4$, and Rspo 1 in knockout gonads at $10.5 \mathrm{dpc}$. Levels of Fox/2, another major player in ovarian development (Ottolenghi et al., 2007), are also reduced, suggesting that the entire program of ovarian differentiation is delayed. These results support a role for $S f 1$ in promoting ovarian differentiation.

These data extend our understanding of SF1 as a factor required for early gonadal development by demonstrating clear consequences for testis and ovarian development in a hypomorphic in vivo model of $S f 1$ expression. Our results affirm an important role for SF1 in ensuring normal testis differentiation and implicate this factor in regulating early ovarian development. Future experiments will be required to determine which components of the ovarian program are regulated by SF1.

\section{Materials and Methods}

\section{Mouse strains}

Embryos were collected from timed matings, with noon of the day on which the mating plug was observed designated $0.5 \mathrm{dpc}$. The AGFP transgenic mouse line constitutively expressing EGFP from an autosome (Hadjantonakis et al., 1998) was a gift from Andras Nagy. The mouse line containing a null allele for Cited2 on the C57Bl/6 background has been described previously (Barbera et al., 2002). Embryo sex was determined by Zfy PCR (Hogan et al., 1994).

\section{Antibodies and immunofluorescence}

The following antibodies were used: Rabbit anti-SOX9 antibody (Wilhelm et al., 2005), Rat anti-platelet endothelial cell adhesion molecule-1/CD31 (PECAM-1, 1:200, BD Biosciences), Mouse antiOCT4 (1:50, Santa Cruz Biotechnology). Secondary antibodies, goat anti-rat Alexa Fluor 594, goat anti-rabbit Alexa Fluor 488, and goat antimouse 594 were obtained from Invitrogen. Whole mount immunofluorescence (Combes et al., 2009) and section immunofluorescence 
(Wilhelm et al., 2005) was performed as described.

\section{Migration assay}

Mice carrying the Cited2 null allele were bred with AGFP mice to produce GFP-positive Cited2t/- offspring. These mice were then used for timed pregnancies to obtain GFP-positive mesonephroi which were Cited $2+/$ or Cited $2 \%$. The mesonephric cell migration assay (Martineau et al., 1997), adapted for use with GFP (Nishino et al., 2000), was performed and quantified as described in (Combes et al., 2009). Some images displayed in Fig. 2 have been rotated and displayed on a black background for presentation purposes.

\section{RNA isolation and quantitative real time RT-PCR}

Gonads (with mesonephroi at $\leq 11.5 \mathrm{dpc}$, without at $>11.5 \mathrm{dpc}$ ) were dissected from embryos in PBS and total RNA was immediately isolated using the Micro RNA kit (Qiagen) as per manufacturers' instructions, including the optional DNase/genomic DNA degradation step. cDNA was synthesised from $1 \mu \mathrm{g}$ of RNA by reverse transcription (Superscript III, Invitrogen) using random primers (Promega) according to manufacturers' instructions. The ABIPrism-7000 Sequence Detector System was used to analyse relative cDNA levels. Quantitative RT-PCR experiments were performed in triplicate and repeated on three independent biological samples each representing two pooled gonads. Results are represented as the average of the experimental value, with error estimated by standard error of the mean. Samples were analysed in $25 \mu \mathrm{l}$ reactions containing $1 \mu \mathrm{lcDNA}$ prepared as described above, SYBR Green PCR Master Mix (Applied Biosystems) and $1 \mu \mathrm{l}$ each of $3.75 \mu \mathrm{M}$ forward and reverse primers. Cycling conditions began with an initial $10 \mathrm{~min}$ step at $95^{\circ} \mathrm{C}$ followed by 40 cycles of $95^{\circ} \mathrm{C}$ for $15 \mathrm{sec}$ and $60^{\circ} \mathrm{C}$ for $1 \mathrm{~min}$ in a twostep thermal cycle. Dissociation curves were analysed for each primer set and cDNA samples were normalised against $18 S$ rRNA using the $2^{-\Delta \Delta C T}$ method. Primer sequences (5' to 3' forward, 5' to 3' reverse) were:

185 GATCCATTGGAGGGCAAGTCT, CCAAGATCCAACTACGAGCTTTTT;

Sf1 TTCGTCTGTCTCAAGTTCCTCATC, CCTTTACGAGGCTGTGGTTGTT;

Wnt4 CTGGACTCCCTCCCTGTCTTT, CATGCCCTTGTCACTGCAA;

Rspo1 CGACATGAACAAATGCATCA, CTCCTGACACTTGGTGCAGA;

Fox/2 GCTACCCCGAGCCCGAAGAC GTGTTGTCCCGCCTCCCTTG;

Sox9 AGTACCCGCATCTGCACAAC, TACTTGTAATCGGGGTGGTCT;

Fgf9 CTATCCAGGGAACCAGGAAAGA, CTCGTTCATGCCGAGGTAGAG.

\section{Acknowledgements}

We thank Wendy Chua and Kylie Lopes Floro for technical assistance, and Josephine Bowles for critical comments on the manuscript. Confocal microscopy was performed at the ACRF/IMB Dynamic Imaging Centre for Cancer Biology, established with the support of the Australian Cancer Research Foundation. This work was supported by research grants from the Australian Research Council and the National Health and Medical Research Council of Australia.

\section{References}

ARANGO, N.A., LOVELL-BADGE, R. and BEHRINGER, R.R. (1999). Targeted mutagenesis of the endogenous mouse Mis gene promoter: in vivo definition of genetic pathways of vertebrate sexual development. Cel/99: 409-419.

BAMFORTH, S.D., BRAGANCA, J., ELORANTA, J.J., MURDOCH, J.N., MARQUES, F.I., KRANC, K.R., FARZA, H., HENDERSON, D.J., HURST, H.C. and BHATTACHARYA, S. (2001). Cardiac malformations, adrenal agenesis, neural crest defects and exencephaly in mice lacking Cited2, a new Tfap2 co-activator.
Nat Genet 29: 469-474.

BARBERA, J.P., RODRIGUEZ, T.A., GREENE, N.D., WENINGER, W.J., SIMEONE, A., COPP, A.J., BEDDINGTON, R.S. and DUNWOODIE, S. (2002). Folic acid prevents exencephaly in Cited2 deficient mice. Hum Mol Genet 11: 283-293.

BUAAS, F.W., VAL, P. and SWAIN, A. (2009). The transcription co-factor CITED2 functions during sex determination and early gonad development. Hum Mol Genet.

BULLEJOS, M. and KOOPMAN, P. (2005). Delayed Sry and Sox9 expression in developing mouse gonads underlies B6-Y(DOM) sex reversal. Dev Bio/278: 473-481.

CAPEL, B. (2000). The battle of the sexes. Mech Dev 92: 89-103.

CHASSOT, A.A., RANC, F., GREGOIRE, E.P., ROEPERS-GAJADIEN, H.L., TAKETO, M.M., CAMERINO, G., DE ROOIJ, D.G., SCHEDL, A. and CHABOISSIER, M.C. (2008). Activation of beta-catenin signaling by Rspo1 controls differentiation of the mammalian ovary. Hum Mol Genet17: 1264-1277.

COMBES, A.N., WILHELM, D., DAVIDSON, T., DEJANA, E., HARLEY, V., SINCLAIR, A. and KOOPMAN, P. (2009). Endothelial cell migration directs testis cord formation. Dev Bio/326: 112-120.

COOL, J., CARMONA, F.D., SZUCSIK, J.C., CAPEL, B. (2008). Peritubular myoid cells are not the migrating population required for testis cord formation in the $X Y$ gonad. Sex Dev2: 128-33.

HACKER, A., CAPEL, B., GOODFELLOW, P. and LOVELL-BADGE, R. (1995). Expression of Sry, the mouse sex determining gene. Development 121: 16031614.

HADJANTONAKIS, A.K., GERTSENSTEIN, M., IKAWA, M., OKABE, M. and NAGY, A. (1998). Generating green fluorescent mice by germline transmission of green fluorescent ES cells. Mech Dev 76: 79-90.

HOGAN, B., BEDDINGTON, R., COSTANTINI, F. and LACY, E. (1994). Manipulating the mouse embryo: A laboratory manual. Cold Spring Habor Laboratory Press. pp 497., Cold Spring Harbor, New York.

IKEDA, Y., TAKEDA, Y., SHIKAYAMA, T., MUKAI, T., HISANO, S. and MOROHASHI K.I. (2001). Comparative localization of Dax-1 and Ad4BP/SF-1 during development of the hypothalamic-pituitary-gonadal axis suggests their closely related and distinct functions. Dev Dyn 220: 363-376.

JEAYS-WARD, K., HOYLE, C., BRENNAN, J., DANDONNEAU, M., ALLDUS, G. CAPEL, B. and SWAIN, A. (2003). Endothelial and steroidogenic cell migration are regulated by WNT4 in the developing mammalian gonad. Development 130 : 3663-3670.

JEYASURIA, P., IKEDA, Y., JAMIN, S.P., ZHAO, L., DE ROOIJ, D.G., THEMMEN, A.P., BEHRINGER, R.R. and PARKER, K.L. (2004). Cell-specific knockout of steroidogenic factor 1 reveals its essential roles in gonadal function. Mol Endocrino/ 18: 1610-1619.

KIM, Y., KOBAYASHI, A., SEKIDO, R., DINAPOLI, L., BRENNAN, J., CHABOISSIER, M.C., POULAT, F., BEHRINGER, R.R., LOVELL-BADGE, R. and CAPEL, B. (2006). Fgf9 and Wnt4 act as antagonistic signals to regulate mammalian sex determination. PLOS Bio/4: e187.

LIU, C.F., BINGHAM, N., PARKER, K. and YAO, H.H. (2009). Sex-specific roles of beta-catenin in mouse gonadal development. Hum Mol Genet 18: 405-417.

LUO, X., IKEDA, Y. and PARKER, K.L. (1994). A cell-specific nuclear receptor is essential for adrenal and gonadal development and sexual differentiation. Cell 77: 481-490.

MAATOUK, D.M., DINAPOLI, L., ALVERS, A., PARKER, K.L., TAKETO, M.M. and CAPEL, B. (2008). Stabilization of beta-catenin in XY gonads causes male-tofemale sex-reversal. Hum Mol Genet 17: 2949-2955.

MARTINEAU, J., NORDQVIST, K., TILMANN, C., LOVELL-BADGE, R. and CAPEL, B. (1997). Male-specific cell migration into the developing gonad. Curr Bio/7: 958-968.

MONIOT, B., DECLOSMENIL, F., BARRIONUEVO, F., SCHERER, G., ARITAKE, K., MALKI, S., MARZI, L., COHEN-SOLAL, A., GEORG, I., KLATTIG, J. et al. (2009). The PGD2 pathway, independently of FGF9, amplifies SOX9 activity in Sertoli cells during male sexual differentiation. Development 136: 1813-1821.

NISHINO, K., KATO, M., YOKOUCHI, K., YAMANOUCHI, K., NAITO, K. and TOJO, H. (2000). Establishment of fetal gonad/mesonephros coculture system using EGFP transgenic mice. J Exp Zoo/286: 320-327.

OTTOLENGHI, C., PELOSI, E., TRAN, J., COLOMBINO, M., DOUGLASS, E., NEDOREZOV, T., CAO, A., FORABOSCO, A. and SCHLESSINGER, D. 
(2007). Loss of Wnt4 and Foxl2 leads to female-to-male sex reversal extending to germ cells. Hum Mol Genet 16: 2795-2804.

PARK, S.Y., MEEKS, J.J., RAVEROT, G., PFAFF, L.E., WEISS, J., HAMMER, G.D. and JAMESON, J.L. (2005). Nuclear receptors Sf1 and Dax1 function cooperatively to mediate somatic cell differentiation during testis development. Deve/opment 132: 2415-2423.

SADOVSKY, Y., CRAWFORD, P.A., WOODSON, K.G., POLISH, J.A., CLEMENTS, M.A., TOURTELLOTTE, L.M., SIMBURGER, K. and MILBRANDT, J. (1995). Mice deficient in the orphan receptor steroidogenic factor 1 lack adrenal glands and gonads but express $\mathrm{P} 450$ side-chain-cleavage enzyme in the placenta and have normal embryonic serum levels of corticosteroids. ProcNat/Acad SciUSA 92: 10939-10943.

SEKIDO, R. and LOVELL-BADGE, R. (2008). Sex determination involves synergistic action of SRY and SF1 on a specific Sox9 enhancer. Nature 453: 930-934.

TOMIZUKA, K., HORIKOSHI, K., KITADA, R., SUGAWARA, Y., IBA, Y., KOJIMA, A., YOSHITOME, A., YAMAWAKI, K., AMAGAI, M., INOUE, A. et al. (2008). Rspondin1 plays an essential role in ovarian development through positively regulating Wnt-4 signaling. Hum Mol Genet 17: 1278-1291.

VAINIO, S., HEIKKILA, M., KISPERT, A., CHIN, N. and MCMAHON, A.P. (1999). Female development in mammals is regulated by Wnt-4 signalling. Nature 397 : 405-409.

VAL, P., MARTINEZ-BARBERA, J.P. and SWAIN, A. (2007). Adrenal development is initiated by Cited 2 and $\mathrm{Wt} 1$ through modulation of Sf-1 dosage. Development
134: $2349-2358$.

WENINGER, W.J., LOPES FLORO, K., BENNETT, M.B., WITHINGTON, S.L., PREIS, J.I., BARBERA, J.P., MOHUN, T.J. and DUNWOODIE, S.L. (2005) Cited2 is required both for heart morphogenesis and establishment of the leftright axis in mouse development. Development 132: 1337-1348.

WILHELM, D. and ENGLERT, C. (2002). The Wilms tumor suppressor WT1 regulates early gonad development by activation of Sf1. Genes Dev16: 18391851.

WILHELM, D., HIRAMATSU, R., MIZUSAKI, H., WIDJAJA, L., COMBES, A.N. KANAI, Y. and KOOPMAN, P. (2007). SOX9 regulates prostaglandin D synthase gene transcription in vivo to ensure testis development. J Bio/Chem282: 10553-10560.

WILHELM, D., MARTINSON, F., BRADFORD, S., WILSON, M.J., COMBES, A.N., BEVERDAM, A., BOWLES, J., MIZUSAKI, H. and KOOPMAN, P. (2005). Sertoli cell differentiation is induced both cell-autonomously and through prostaglandin signaling during mammalian sex determination. Dev Bio/287: 111-124.

WITHINGTON, S.L., SCOTT, A.N., SAUNDERS, D.N., LOPES FLORO, K., PREIS, J.I., MICHALICEK, J., MACLEAN, K., SPARROW, D.B., BARBERA, J.P. and DUNWOODIE, S.L. (2006). Loss of Cited2 affects trophoblast formation and vascularization of the mouse placenta. Dev Bio/294: 67-82.

YIN, Z., HAYNIE, J., YANG, X., HAN, B., KIATCHOOSAKUN, S., RESTIVO, J., YUAN, S., PRABHAKAR, N.R., HERRUP, K., CONLON, R.A. et al. (2002). The essential role of Cited2, a negative regulator for HIF-1alpha, in heart development and neurulation. Proc Nat/ Acad Sci USA 99: 10488-10493.

\section{Further Related Reading, published previously in the Int. J. Dev. Biol.}

See Special Issue Pattern Formation edited by Michael K. Richardson and Cheng-Ming Chuong at:

http://www.ijdb.ehu.es/web/contents.php?vol=53\&issue=5-6

The spatio-temporal pattern of testis organogenesis in mammals - insights from the mole

Francisco D. Carmona, Darío G. Lupiáñez, José-Ezequiel Martín, Miguel Burgos, Rafael Jiménez and Federico Zurita

Int. J. Dev. Biol. (2009) 53: 1035-1044

Foetal germ cells: striking the balance between pluripotency and differentiation Patrick Western

Int. J. Dev. Biol. (2009) 53: 393-409

Aard is specifically up-regulated in Sertoli cells during mouse testis differentiation Terje Svingen, Annemiek Beverdam, Pali Verma, Dagmar Wilhelm and Peter Koopman Int. J. Dev. Biol. (2007) 51: 255-258

Effects of FGF9 on embryonic Sertoli cell proliferation and testicular cord formation in the mouse

Louise Willerton, Robert A. Smith, David Russell and Sarah Mackay

Int. J. Dev. Biol. (2004) 48: 637-643

Developmental regulation of expression of Ran/M1 and Ran/M2 isoforms of RanGTPase in mouse testis

Pedro P López-Casas, Luis A López-Fernández, Mario Párraga, Dora B Krimer and Jesús del Mazo

Int. J. Dev. Biol. (2003) 47: 307-310

Differentiation of mouse primordial germ cells into female or male germ cells

N Nakatsuji and S Chuma

Int. J. Dev. Biol. (2001) 45: 541-548

Wilms' tumor suppressor gene (WT1) as a target gene of SRY function in a mouse ES cell line transfected with SRY.

Y Toyooka, S S Tanaka, O Hirota, S Tanaka, N Takagi, K Yamanouchi, H Tojo and C Tachi Int. J. Dev. Biol. (1998) 42: 1143-1151

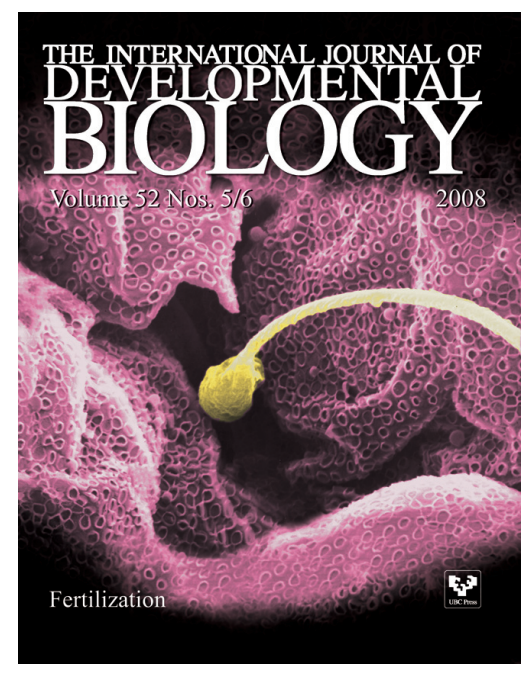

5 yr ISI Impact Factor $(2008)=3.271$

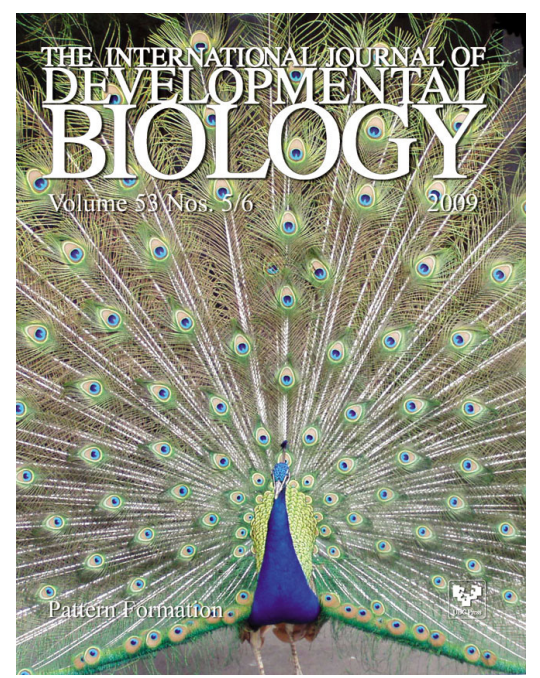

